\title{
Seven missing damaging earthquakes in Upper Valtiberina (Central Italy) in 16th-18th century: research strategies and historical sources
}

\author{
Dante Mariotti and Emanuela Guidoboni \\ SGA Storia Geofisica Ambiente, Bologna, Italy
}

\begin{abstract}
The Italian earthquake catalogue is considered to be fairly complete starting from the 17th century and for classes of earthquakes of magnitude greater than 5.5. However, dedicated historical research has highlighted the fact that even in areas believed to be well-recognised from the seismological standpoint, authoritative traces of local earthquakes that have caused damage may also emerge. In this study, we present the results of a pilot study performed for the Upper Valtiberina within the framework of the INGV research programmes in the years 1999-2001, expanded and revised in 2005. The study highlighted seven local medium intensity earthquakes, which nonetheless caused damage to buildings. Besides the results, which as a whole have allowed us to classify 18 effects in 6 sites, the research method adopted is also presented. It is a method applicable to other cases as well, where the chronological earthquake indicators are unknown, being capable of unearthing earthquakes unknown to the tradition of seismological studies and the catalogues in use. A selection of the manuscript sources used is presented in the Appendix.
\end{abstract}

Key words missing earthquakes - historical seismology - Italian earthquake catalogues - Upper Valtiberina

\section{Introduction}

The territory of Upper Valtiberina, formed by the first stretch of the River Tiber, about $60 \mathrm{~km}$ in length, is situated on the border between Eastern Tuscany and Northern Umbria, and is one of the most important seismic areas in the whole of the Central Apennines. Numerous elements concerning the known earthquakes localised in this area were already available within the scope of the re-

Mailing address: Dr. Dante Mariotti, SGA Storia Geofisica Ambiente, Via del Battiferro 10b, 40129 Bologna, Italy; e-mail: mariotti@sga-storiageo.it search performed starting in 1991. The effects caused by the known earthquakes are quite well defined (see the summary in table I).

As regards the two main urban centres of the area under examination here, Sansepolcro and Città di Castello, it should be remembered that in the past they had both suffered damage effects equal to the IX degree on the MCS scale. In Sansepolcro, the seismic sequence of December 1352-January 1353 was particularly destructive. In Città di Castello the maximum destructive effects were caused by the earthquake on 30th September 1789: for both of these, see Castelli et al. (1997) and Boschi et al. (2000); in particular for the 1789 earthquake Castelli (2002) has elaborated a very accurate effects scenario for the urban area.

The aim of this study is not to make a new evaluation of the seismic hazard of these two historical towns, but to identify the unknown earthquakes in the area being examined and to make 
Table I. Summary of the known earthquakes in the Upper Valtiberina area from CFTI (Boschi et al., 2000) and CPTI 04 (CPTI Working Group, 2004). Me=equivalent magnitude, according to Gasperini and Ferrari (2000); $\mathrm{Mw}=$ moment magnitude, according to CPTI Working Group (2004).

\begin{tabular}{|c|c|c|c|c|c|c|c|}
\hline Date & UTime & Location & Lat & Long & $\mathrm{I}_{0}$ & $\mathrm{Me}$ & $\mathrm{Mw}$ \\
\hline 1270 & - & Sansepolcro & 43.57 & 12.14 & VII-VIII & & 5.4 \\
\hline 13521225 & 1600 & Sansepolcro & 43.48 & 12.15 & VIII-IX & 5.7 & \\
\hline 13530101 & 0630 & Sansepolcro & 43.57 & 12.13 & VIII & 5.4 & \\
\hline 1358 & - & Sansepolcro & 43.57 & 12.14 & VI-VII & & 5.0 \\
\hline 13891018 & - & Appennino umbro-marchigiano & 43.53 & 12.37 & VIII-IX & 6.0 & \\
\hline 14561209 & - & Sansepolcro & 43.57 & 12.14 & V-VI & & 4.6 \\
\hline 14580426 & 1215 & Valtiberina & 43.52 & 12.18 & VIII-IX & 5.7 & \\
\hline 14650517 & - & Gubbio & 43.35 & 12.58 & VI & & 4.8 \\
\hline 14661226 & - & Gubbio & 43.35 & 12.58 & VI & & 4.8 \\
\hline 147103 & - & Piccione & 43.25 & 12.50 & VI & & 4.8 \\
\hline 1489 & - & Sansepolcro & 43.57 & 12.14 & VII & & 5.2 \\
\hline 15041101 & - & Bibbiena & 43.70 & 11.82 & VII & 4.9 & \\
\hline 15951030 & - & Gubbio & 43.35 & 12.58 & V-VI & & 4.6 \\
\hline 16940408 & - & Sansepolcro & 43.57 & 12.14 & VII & & 5.1 \\
\hline 175208 & - & Città di Castello & 43.47 & 12.25 & VI & & 4.8 \\
\hline 17871226 & - & Bibbiena & 43.75 & 11.75 & VI & & 4.8 \\
\hline 17890930 & 1045 & Valtiberina & 43.52 & 12.22 & IX-X & 5.8 & \\
\hline 18240812 & 07 & Pieve S.Stefano & 43.75 & 12.00 & VI & & 4.8 \\
\hline 18560605 & - & Pieve S.Stefano & 43.67 & 12.04 & VI-VII & & 5.0 \\
\hline 18650921 & 2050 & Umbria settentrionale & 43.28 & 12.32 & VII & 5.2 & \\
\hline 18770303 & 010926 & Chiusa Verna & 43.67 & 11.83 & VI & & 4.8 \\
\hline 18911208 & 1930 & Monterchi & 43.42 & 12.13 & VI & & 4.8 \\
\hline 18921121 & - & Città di Castello & 43.48 & 12.27 & $\mathrm{~V}-\mathrm{VI}$ & & 4.6 \\
\hline 18971218 & 0724 & Appennino umbro-marchigiano & 43.50 & 12.38 & VII & 5.2 & \\
\hline 18990708 & 2258 & Badia & 43.83 & 11.95 & $\mathrm{~V}-\mathrm{VI}$ & & 4.6 \\
\hline 19020627 & 1648 & Casentino & 43.64 & 11.86 & VI & & 4.8 \\
\hline 19130729 & 222432 & Badia & 43.80 & 11.90 & VI & & 4.8 \\
\hline 19130809 & 0145 & Monte Leto & 43.40 & 12.50 & $\mathrm{~V}-\mathrm{VI}$ & & 4.6 \\
\hline 19170426 & 0935 & Valtiberina & 43.47 & 12.13 & IX-X & 6.0 & \\
\hline 19180322 & 044320 & Monterchi & 43.50 & 12.20 & V-VI & & 4.6 \\
\hline 19191025 & 1351 & Monterchi & 43.57 & 12.13 & VI & & 5.1 \\
\hline 19210405 & 1740 & Castiglione & 43.30 & 12.50 & VI & & 4.8 \\
\hline 19271130 & 025824 & Monte Leto & 43.40 & 12.50 & VI & & 4.8 \\
\hline 19480613 & 0633 & Valtiberina & 43.60 & 12.13 & VII & 5.1 & \\
\hline 19610323 & 0101 & Gubbio & 43.36 & 12.54 & VI-VII & & 4.4 \\
\hline 19630203 & 1005 & Pietralunga & 43.43 & 12.45 & VI & & 4.8 \\
\hline 19630520 & 04 & Monte Leto & 43.40 & 12.50 & VI & & 4.8 \\
\hline 19650804 & 114953 & Borgo Pace & 43.60 & 12.30 & VI & & 4.8 \\
\hline 19690809 & 092057 & Chiusa Verna & 43.70 & 11.93 & VI & & 4.8 \\
\hline 19840429 & 0502 & Umbria settentrionale & 43.22 & 12.52 & VIII & 5.6 & \\
\hline
\end{tabular}


available new data to the researchers on the seismicity of Upper Valtiberina together with the original sources used. The research was performed between 1999 and 2001 (SGA-INGV, 1999, 2000-2001); the identified sources have subsequently been re-examined and revised. The result has been the identification of seven hitherto unknown earthquakes, which had occurred between 1558 and 1731, causing damage effects in one or more locations of the Upper Valtiberina. Some of these earthquakes $(1559,1668,1731)$ are listed by Castelli (2004), a study that mainly focuses on the historical seismicity of the Casentino area, a region bordering the Upper Valtiberina to the north.

\section{Historical characteristics of the study area}

From the historical standpoint, the Upper Valtiberina has always appeared to be somewhat isolated from the major centres of the bordering regions. In actual fact, this had allowed the more important urban centres, such as Sansepolcro and Città di Castello, to enjoy a great deal of political autonomy until the 15th century, which extended across the whole of the surrounding territory. Subsequently, the area was subjected to lengthy disputes between the local lordships up until the definitive conquest by the Grand Duchy of Tuscany in the north-western part of the region, including Sansepolcro, and the Papal State in the south-eastern part, including Città di Castello. This meant that this territory was administered by two different States until the Unification of Italy (1861), making the study of the documentary sources in the different competent archival offices twice as complex, as a result of the concurrent presence of two different centres of State power.

The historical documentation for this area, which has important cultural roots, is generally preserved starting from the 13th century. In particular, from the 14th to the 16th centuries, the documentation is kept in the Municipal Historical Archives of Sansepolcro and Città di Castello. Starting from the 17 th century the documentation produced by local administrators can be added to by that produced by the respective central administrative bodies, that is, the Tuscan Grand Duchy administration for
Sansepolcro and the Pontifical administration for Città di Castello. The documentary collections of the two central administrations are kept at the State Archives of Florence and at the State Archives of Rome, respectively.

\section{Research strategies for detecting earthquakes unknown to the catalogues in use}

The case we present here also lends itself to some considerations in regard to the completeness of the earthquake catalogues in use in Italy. As is by now well-known from literature studies, the Italian catalogues in use (Boschi et al., 2000; CPTI Working Group, 2004) are only considered to be complete for high classes of intensity (from the IX degree), starting from the 17 th century. Of course, for lower classes of intensity the catalogues are still largely incomplete, even for periods and areas that are highly documented, such as those of Tuscany and Umbria regions. This derives from the fact that the large amount of work carried out over the past twenty years on the catalogue has mostly concerned reviews of already known earthquakes (several thousand) serving to improve the macroseismic picture and to allow for new, more accurate calculations of the parameters.

It should be pointed out that systematic research has been performed into the primary sources only for the earthquakes from antiquity to the Middle Ages (Guidoboni et al., 1994; Guidoboni and Comastri, 2005). The exhaustiveness of this analysis is the result of the relatively small number of texts available. For the Italian sources of the central and early Middle Ages (11th-15th centuries) and the subsequent periods, the complexity and the sheer mass of documentation available makes it possible to carry out targeted research developed on the grounds of chronological indicators and for specific areas (a balance of this research is in Guidoboni, 2000).

However, research using particular study methods has been performed with the aim of identifying the earthquakes unknown to the catalogues in use and improving the known historical series. For such cases, some strategies have 
been honed to systematically examine a series of sources capable of filtering different levels of collective and territorial memory (for a summary, see Mariotti et al., 2000). From such perusals the chronological indicators may indeed emerge that are subsequently able to shape the other research phases.

As can also be seen in the following paragraphs, the identification of these new earthquakes has been enabled by a series of cross-references between the different kinds of sources: in some cases (earthquakes in 1558, 1559, 1668, $1725)$ from the less well-known private memorials (as in the cases examined here of handwritten notes in 16th century codes) we have moved on to the analysis of the archival documentation. In other cases (1690 earthquake), the traces have emerged directly from the central or local administration, and evidence has not been detected in the memorial sources owing to chronological discontinuities in the narratives or due to their complete absence. In yet other cases $(1693,1731)$, the traces of the earthquake could also be found in newspapers and gazettas. These news items were soon forgotten, because other far more destructive earthquakes (those of Eastern Sicily on 9th and 11th January 1693, and the one occurring in the Foggia area on 20th March 1731) attracted the public's attention more.

\section{Results of the historical analysis}

\subsection{The seismic sequence in February 1558}

In the mid-16th century Sansepolcro was part of the Duchy of Tuscany (from 1569 the Grand Duchy), while Città di Castello belonged to the Papal State. Sansepolcro was the main centre of the Upper Valtiberina, with over 5000 inhabitants (5041 in 1551), mostly engaged in agriculture and the wool and silk trade.

A first trace of the 8th-10th February 1558 earthquake has been retrieved from the contemporary Memorie (1543-1591, ed. 1915) by Berto Alberti (1525-1599), a painter, carver and architect of Sansepolcro. Thanks to this earliest chronological indication, research has been conducted into the administrative documentation and into other local memorial sources in order to test the reliability of the information and to enhance our understanding of the event.

At the Municipal Historical Archives of Sansepolcro, within the series II (Riforme, provvisioni e deliberazioni dei consigli, reg. 14), we have found a long memorial on this earthquake written by the chancellor of the community on 27th February 1558, bearing witness to the damage in Sansepolcro and Città di Castello (see Appendix, doc. 1). On the grounds of this highly authoritative report, which in spite of its personal tone is entrusted to the official records of the community, we have also evaluated the $\mathrm{V}$ series (Copialettere del magistrato e suppliche al principe, regs. 2-3), and the XXX series (Memorie della Comunità, reg. 4): the result was negative, however.

A testimony to this earthquake was also found in the Municipal Historical Archives of Città di Castello. In register 58 of the Riformanze, the chancellor of the municipality described the event with these words: «Terremotus ingens de presenti anno 1558» («The very strong earthquake of this year 1558»). Beneath that note a blank space was left in which a more detailed memoir of the occurrence could later be added. However, that text remained unwritten.

Other archival research has produced negative results: at the State Archives of Arezzo the fond Antico Comune, series Deliberazioni e partiti dei priori e del consiglio generale (regs. 23-24) and Registri di lettere dei cancellieri (reg. 6) has been examined, although no further indications were found. The attempt to assess the central administration documentation, preserved at the State Archives of Florence, was made very difficult as a result of the 1966 flood damage, the effects of which are still being felt. A case in point is the series Rapporti de capi maestri of the fond Nove conservatori del dominio e della giurisdizione fiorentina, which comprises the chronological range 1558-1633, which cannot yet be consulted as it is undergoing restoration. It contains the experts' reports concerning the public works to be carried out to the rivers, buildings, roads and mills, which may well contain useful information as regards possible earthquake damage. The analysis of other fonds (Capitani di parte guelfa, Numeri neri, Suppliche, file 706; Cinque conservatori del contado e dominio fiorentino, series 
Lettere, files 348-350, Copialettere, files 310312, Deliberazioni, regs. 134-135) has produced negative results.

As regards the memorial sources, we have used fairly reliable contemporary chronicles. Apart from the previously cited Berto Alberti, we have used the third part (1490-1573, ed. 1970) of the Historia di Perugia by Pompeo Pellini (15231594). This source reports some slightly different chronological indications as compared with the others; indeed, it dates the earthquakes to March 1558 instead of February. However, it seems quite reasonable to suppose that the same sequence is being referred to, as Pellini, apart from mentioning Perugia, recalls that the worst damage was caused to Città di Castello. Also, as regards the starting day of the sequence, there is no exact match between the contemporary sources: Berto Alberti dates it to the 8th and the memoir of the Council chancellor of Sansepolcro to the 9th February 1558. The discrepancy is, however, quite likely to be merely apparent, due to the use of 'Italian time', which meant that the day was counted as starting from day-break (so the system was rather fluid and variable).

\subsubsection{February seismic sequence}

The start of the seismic crisis is set by the sources contemporary to the 8th February 1558; the sequence then continued for over a month. The strongest shocks mentioned are the following three:

8th February 1558 about 22:15 UT (5 o'clock at night according to 'Italian time') two strong shocks very much scared all of the inhabitants of Città di Castello; about 23:15 UT (6 o'clock according to 'Italian time') other light tremors in Sansepolcro;

9th February 1558 about 4:15 UT (11 o'clock according to 'Italian time') the strongest shock occurred: it caused damage in Sansepolcro as well as in Città di Castello, and was felt in Perugia; about 6:15 UT (13 o'clock, 'Italian time') strong tremor in Sansepolcro. In the first two days, 8th and 9th February, over 18 shocks were felt.

10th February 1558 about 12:15 UT (19 o'clock, 'Italian time') another strong shock in Sansepolcro.
In Città di Castello the houses were seriously damaged and they all had to be propped up; in Sansepolcro many chimney pots either fell down or cracked, and the walls and roofs of the buildings partly caved in.

\subsection{Earthquake on 11th April 1559}

Just over a year later, in April 1559, a strong seismic activity started in the same area. The clues for identifying this new event have been provided by the research into the previous 1558 sequence. Indeed, our investigative strategy required the analysis of the memorial sources to be complete for each work, and the analysis of the administrative sources extended chronologically so far as to include at least the three-year period subsequent to the identified seismic event. Even in this case we adopted the chronological yardstick of Berto Alberti's Memorie (ed. 1915), and then moved on to analyse the administrative documentation.

At the Municipal Historical Archives of Sansepolcro, within series II (Riforme, provvisioni e deliberazioni dei consigli, reg. 14), we retrieved another official memoir, written on the same day as the earthquake by a first person narrator who was still fear-stricken at the time of writing, perhaps the same chancellor of the Council, reporting the damage to Sansepolcro (see fig. 1 and Appendix, doc. 2). A painstaking analysis of the other administrative and institutional documentation has instead produced a negative outcome, such as: series V (Copialettere del magistrato e suppliche del principe, regs. 2-3) and series XXX (Memorie della Comunità, reg. 4). At the Municipal Historical Archives of Città di Castello a short report was also found on the event that bears witness to the local effects of the earthquake (Appendix, doc. 3). That record was written by the chancellor of the Council among the drafts of the Riformanze (reg. AA). Instead the surveys carried out at the State Archives of Arezzo, in the series Deliberazioni e partiti dei priori e del consiglio generale (reg. 24) and Registri di lettere dei cancellieri (regs. 6-7) of the fond Antico Comune produced a negative outcome.

The documentary research then moved across to the State Archives of Florence to ascer- 


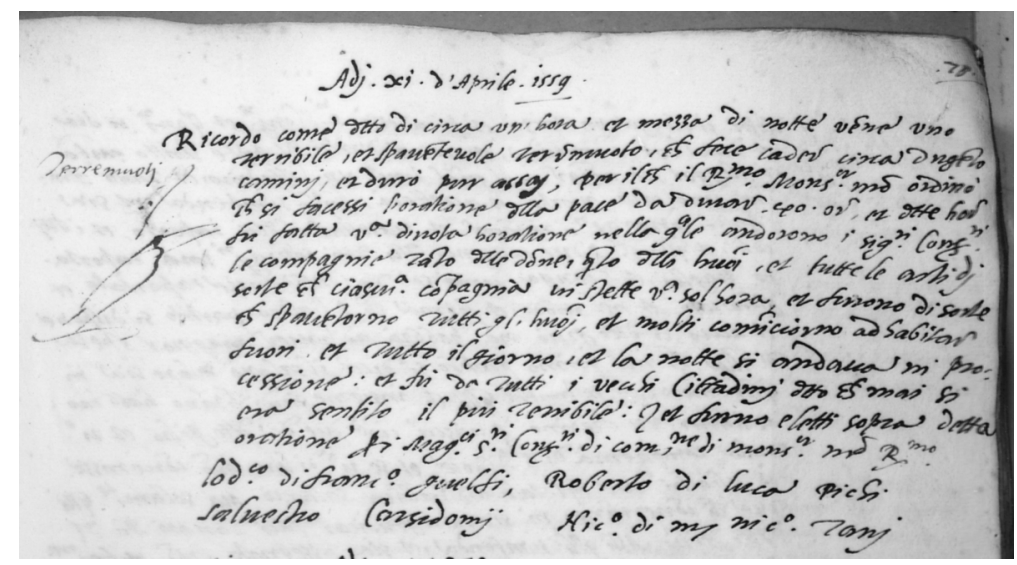

Fig. 1. Official memoir on the 11th April 1559 earthquake written by the chancellor of the community of Sansepolcro (see the transcription of the text in the Appendix, doc. 2).

tain whether the central administration had been involved after the damage. In the series Lettere (file 352) of the fond Cinque conservatori del contado e dominio fiorentino they have been found two letters of the ducal vicar of Pieve Santo Stefano, another important town in the Upper Valtiberina, Zanobi Guidotti. These letters were written on 26th April and on 22nd May 1559 and report damage to the vicarage building and the financial resources needed to repair that damage (Appendix, docs. 4-5). Strictly speaking, this does not mean that this was the only damage suffered at Pieve Santo Stefano. As a matter of fact, it is worth bearing in mind that the fiscal and administrative policies of that period did not envisage tax incentives or economic aid to encourage the repair of privately-owned buildings. So the lack of archival sources regarding the conditions of the housing stock does not come as a complete surprise.

Moreover, no information was found in the series Copialettere (reg. 313) and Deliberazioni (reg. 136) of the same magistrature, Cinque conservatori del contado e dominio fiorentino, and in the series Suppliche (file 707) of the fond Capitani di parte guelfa, Numeri neri. As already mentioned above, the documentation of the series Rapporti de capi maestri (1558-1633) is still beyond consultation. To try to gather more information on the event we have tried to assess the sub- stance of the documentation preserved at the Municipal Historical Archives of Pieve Santo Stefano. However, this attempt has been hampered by the destruction and the dispersion following an overflowing of the River Tiber and the destruction suffered in this area during World War II (the town is not far from the Gothic line), which has meant that the archives only preserve the postUnification documentation, that is after 1861 .

The earthquake occurred on 11th April 1559 at about 20:00 UT (half past one o'clock at night, according to the 'Italian time'). The worst-hit site was Sansepolcro, where two hundred chimney pots fell, houses both inside and outside the town collapsed, and the walls of the ancient quarter inside Porta Fiorentina and the church of San Bartolomeo collapsed. At Pieve Santo Stefano the vicarage was damaged. At Città di Castello the earthquake was «satis notabilis» (rather remarkable), but caused no damage. No aftershocks are mentioned either.

\subsection{Earthquake on 22nd August 1668}

A first trace of the earthquake on 22nd August 1668 is contained in an anonymous note written in the manuscript J.107 of the Civic Library of Sansepolcro, which contains some notes such as the continuation of the chronicle of Sansepolcro 
by Francesco Bercordati (16th century). It is reasonable to believe that the note was written by a direct witness, probably the owner of the manuscript. An indirect later source, the Compendio istorico by Francesco Giuseppe Pignani (18th century), preserved in the same library (manuscript J.109), confirms the occurrence of this earthquake. On the basis of this chronological indicator we have performed an archival search aimed at being able to evaluate the effects of the earthquake and to estimate its parameters.

At the Municipal Historical Archives of Sansepolcro we have analysed the documentation in the series II (Riforme, provvisioni e deliberazioni dei consigli, reg. 31) and in the series XXX (Memorie della Comunità, regs. 1, 3-4), which produced a negative outcome: this result has led us to hypothesise that the earthquake did not have damaging effects in Sansepolcro. An equally negative outcome was produced by the research performed at the Municipal Historical Archives of Città di Castello, where the documentation of the series Riformanze (reg. 110) and Lettere (tome 4) was analysed.

The research was extended to the archives of the Apostolic Chamber, preserved at the State Archives of Rome: the documentation relating to the Sacra Congregazione del Buon Governo was evaluated. Within the series II, Atti per luoghi (bundle 1085), we found declarations concerning the effects of this earthquake at Città di Castello. Indeed, two letters of the governor, Girolamo Castromediano, dated 23rd August 1668 (see Appendix, doc. 6) and 4th October 1668, addressed to the prefect of the Congregazione, describe the damage to the building where the governor himself was living. Moreover, a memorial of the community of Città di Castello, dated 16th September 1668 was found, in which it is confirmed that the strong shock caused damage to the governor's building.

The earthquake occurred on 22nd August 1668. The worst-hit site was Città di Castello, where the static conditions of the governor's building, which may have been weakened by previous works, actually got worse. It had to be propped up to avoid further collapse. Although the Sansepolcro shock was strong, causing outbreaks of panic, there was no damage. No information was found about aftershocks.

\subsection{Earthquake on 22nd March 1690}

A fourth unknown event emerged upon evaluating the administrative documentation of the Apostolic Chamber preserved at the State Archives of Rome. In this case, by following a purely topographical rationale, we evaluated the documentation relating to Città di Castello from 1668 to 1730 . Indeed, it is interesting to observe that from the outset no memorial source has provided a chronological indicator for this 1690 earthquake. In the fond Congregazione del Buon Governo, series II (Atti per luoghi, bdl. 1086) we thus found the reports relating to the effects at Città di Castello. These mainly consist of the copy written by the notary Girolamo Carsidonio of a decision taken by the Council of Città di Castello, dated 23rd August 1690, that is, five months after the earthquake. In this document, there is a transcription of a plea presented to the community of Città di Castello by the rector of the Jesuit College, father Filippo Guarnerio (see Appendix, doc. 7). Three more documents have also been found: a letter by Gian Francesco Ruota, governor of Città di Castello, to cardinal Ottoboni, prefect of the Congregazione del Buon Governo, dated 18th February 1691 (Appendix, doc. 8); and two memorials addressed by the Jesuits to the same Congregazione del Buon Governo, dated January and February 1691. All of this documentation concerns the requests for funding addressed by the Jesuits to the community of Città di Castello in order to repair their earthquakedamaged College.

The research then continued at the Municipal Historical Archives of Città di Castello, thanks to the chronological indications which were found and confirmed. We thus assessed the series Riformanze, which even in those years represented a sort of great public diary of the important community events. Inside register 116 a short memoir is preserved written three years later in 1693, on the occasion of the earthquake of 24th February of that year (Appendix, doc. 9). This short text is by the Council chancellor, who set to memory the earthquake in 1693 , and the still very vivid one of the previous earthquake in 1690. He explicitly declared: «I felt them both and felt great fear». The chancellor also wrote that the earthquake in 1693 was «no less» strong 
than the one that had occurred on 22nd March 1690. This hand-written note also represents the only source retrieved actually dating the shock.

The earthquake occurred on 22nd March 1690 about 21:50 UT (4 o'clock at night according to 'Italian time'). At Città di Castello a wall of the Jesuit College was fissured and cracked; at the time extension work was being carried out to it, and it had remained without support due to the prior demolition of the adjacent houses in order to erect the new wing of the building.

Given the current state of research, we know that in that same year, 1690, an earthquake also hit Foligno, about $70 \mathrm{~km}$ away. It is likely that this was a self-standing event, for which no further information is available, however.

\subsection{The seismic sequence on 22 nd-24th February 1693}

This event is attested to by the above-cited note written by the chancellor of the community of Città di Castello, preserved at the local Municipal Historical Archives inserted into the register 116 of the Riformanze (see Appendix, doc. 9). That note contains cursory yet clear information about the effects at Città di Castello and Pietra-lunga, in the present-day province of Perugia. The latter is a small hilltop village (566 $\mathrm{m})$ of Roman origin, which grew in the medieval period near an ancient Benedictine abbey (11th century). The research also extended to the series Lettere (tome 5), but the examination produced no positive results. An equally negative outcome was achieved by the research performed at the Municipal Historical Archives of Sansepolcro, in the series II (Riforme, provvisioni e deliberazioni dei consigli, reg. 33), in the series VII (Corrispondenza dei cancellieri, file 7) and in the series XXX (Memorie della Сотиnità, regs. 1, 3-4).

This seismic event, for which clearly no administrative actions were taken, such as leaving any administrative files, was instead portrayed by the newspaper-style chronicles of the day. However, the public's attention in those months was all turned to the great earthquake of Eastern Sicily, which had destroyed Catania and dozens of towns and villages between 9th and 11th Jan- uary (Guidoboni et al., 2001). The earthquake of 22nd-24th February 1693 hit an area in the Papal State and the news was indeed published in one of the most important news publications for that period and area, that is, the weekly gazetta Bolo-gna. The issue of 17th March 1693 published a report from Rome, dated 7th March, with news on the effects of the earthquake at Città di Castello.

This event is recalled by all the sources as a rapid and pounding sequence consisting of twelve strong shocks, followed by a stronger one.

22nd February: a strong seismic activity started which caused great alarm in all the population of the area of Città di Castello and Pietralunga.

24th February: the strongest shock occurred at about 3:45 UT (half past 10 o'clock at night, 'Italian time').

The worst hit site was Pietralunga, where it was very likely that the church was damaged. The people who happened to be there on the occasion of one of the shocks were forced to flee into the open to escape from the «threatening ruins above». At Città di Castello the shocks caused cracks to houses and churches.

\subsection{Earthquake of 17th-18th April 1725}

A trace of the fifth identified earthquake, which occurred on 17th and 18th April 1725, is preserved in the previously cited Compendio istorico (1758) by Francesco Giuseppe Pignani, preserved in the Civic Library of Sansepolcro (manuscript J.109), regarding the history of that city. Even in this case the chronological indicator rebounded in the archival research, with a negative outcome, however. The perusals were conducted at the Municipal Historical Archives of Sansepolcro in the series II (Riforme, provvisioni e deliberazioni dei consigli, reg. 35), in the series VII (Corrispondenza dei cancellieri, file $10)$ and in the series XXX (Memorie della Comunità, regs. 1-3). This negative outcome has confirmed that the earthquake probably caused no significant damage to the public buildings of Sansepolcro.

At the Municipal Historical Archives of Città di Castello we analysed the series Rifor- 
manze and the series Lettere. In the former we found a memoir on the earthquake, probably written by the Council chancellor, inserted in the register 125 (see Appendix, doc. 10). The examination of the series Lettere (tome 7) instead produced a negative outcome. The documentation of the Apostolic Chamber (Sacra Congregazione del Buon Governo, Atti per luoghi, bdl. 1089) preserved at the State Archives of Rome also produced a negative result.

We have retrieved further information concerning Città di Castello and Fabriano (in the present-day province of Ancona, about $50 \mathrm{~km}$ from Città di Castello) from two gazettes: the Gazzetta di Mantova of 11th May 1725, which reported correspondence from Rome dated 28th April, and the gazetta Bologna of 15th May 1725, which reported correspondence from Rome dated 5th May.

A reference to the effects in the city of Perugia was found in the Diario (1692-1742) by Pietro Vermiglioli, preserved at the Augusta Civic Library of Perugia (manuscript 1398).

\subsubsection{Chronology and effects of the seismic sequence in April 1725}

17th April 1725: the strongest shock took place at about 13:05 UT (quarter to 19 according to the 'Italian time'). It was felt by the people to have a very long duration: it can be reckoned to have lasted about a minute, bearing in mind that the qualitative unit of measurement indicated by the witnesses is the time usually taken to recite two miserere (on these curious qualitative time conversions, in use until watches became more widespread, see Ferrari and Marmo, 1985). Given our present state of knowledge, the worst-hit site was Fabriano where a unspecified number of houses collapsed. However, it should be pointed out that this piece of news has not yet been confirmed in the documentary sources.

At Sansepolcro the shock was described by the witnesses as being «terrible» and «horrible» and perhaps damaged the clock tower. The uncertainty is due to a textual ambiguity owing to the use of the lexical item «crollare» in the cited manuscript by Pignani: as a matter of fact, this verb in Italian is both transitive and intransitive, so it has the double meaning of «scuotere» (to shake, transitive) and «cadere giù» (to fall down, intransitive). Today this verb is mainly used only intransitively (although it has the same meaning when used in the transitive form), whereas in centuries past its intransitive use was preferred. The fact of not having retrieved administrative documentation that bears witness to any damage to this public building (see the preceding paragraph) speaks in favour of the transitive sense of the verb.

At Città di Castello there was slight damage, defined by the witnesses as «not at all remarkable» (nullum notabile damnum). The earthquake was also felt in Perugia. Keeping exclusively to the statements of the official documents, we can deduce that at Città di Cas-tello this earthquake had a considerable impact on the population; as a matter of fact, the same day the gonfalonier summoned the members of the Consiglio di Reggimento and those of the Consiglio di Credenza who went with the nobles and the citizenry to the church of Santa Maria delle Grazie for the public and official religious rites. On the following day, 18th April 1725, the same gonfalonier and the priors visited the cathedral and attended the religious functions.

18th April 1725, at 13:05 hours UT (quarter to 19 , 'Italian time'): at Città di Castello a much lighter shock than the previous one was felt.

The seismic activity continued in a way that was clearly felt by the people for about three days.

\subsection{The sequence on 11th-29th March 1731}

Of this earthquake only the foreshocks were detected by the news «networks» of the day, in this case the Gazzetta di Mantova: as a matter of fact, a correspondence from Florence, dated 20th March, published in the issue of 30th March 1731, refers to the shocks occurring from 11th to 15th March at Pieve Santo Stefano. The news reported the «great apprehension» aroused by the ongoing seismic activity that did not appear to diminish; indeed, it is stated that over 70 strong shocks were counted. However, in the subsequent issues of the news- 
paper nothing else was published about this seismic crisis at Pieve Santo Stefano. What had happened to the reporting system? On 20th March of that year, many kilometres away, a much stronger earthquake had hit the area around Foggia, causing many deaths and much ruin (Boschi et al., 2000). This was sufficient in order not to have information about a local earthquake, a smaller and much less interesting one for the communications network as compared with the interest generated by a much more destructive event. There are many such cases in Italy: this is a grey area where great earthquakes lead to events that are chronologically close being overlooked. It is also for this reason that the research took into account different types of independent sources.

The information on the main shock that hit Pieve Santo Stefano is only contained in a contemporary hand-written diary: the learned Francesco Settimanni (1681-1763), in his $\mathrm{Me}$ morie fiorentine, preserved in many volumes at the State Archives of Florence (manuscripts 125-147), reports his memories of the shocks on the days 11th-15th March 1731 at Pieve Santo Stefano, thus wholly confirming the above-cited journalistic correspondence. The same author also reports the information about the main shock of the sequence, occurring on 29th March, about two weeks afterwards (see Appendix, doc. 11).

However, it is impossible to enhance our understanding of the effects through the administrative documentation of the Municipal Historical Archives of Pieve Santo Stefano because, as has been mentioned in the previous paragraphs, it only keeps the documentation for the postUnification period, i.e. after 1861.

We obtained a negative outcome with our research at the Municipal Historical Archives of Sansepolcro, where we consulted the series II (Riforme, provvisioni e deliberazioni dei consigli, reg. 35), the series VII (Corrispondenza dei cancellieri, file 13) and the series XXX

Table II. Summary of recovered earthquakes in the Upper Valtiberina area; in bold the epicentral parameters calculated with the method of Gasperini and Ferrari (2000).

\begin{tabular}{|c|c|c|c|c|c|}
\hline Date and location & Lat & Long & $\mathrm{I}_{0}$ & Int & $\mathrm{Me}$ \\
\hline 1558 February 9 4:15 UT & 43.51 & 12.19 & VII & & 5.3 \\
\hline Città di Castello & 43.46 & 12.24 & & VII-VIII & \\
\hline Sansepolcro & 43.57 & 12.14 & & VII & \\
\hline Perugia & 43.11 & 12.39 & & $\mathrm{~F}$ & \\
\hline 1559 April 11 20:00 UT & 43.62 & 12.09 & VII & & 5.3 \\
\hline Sansepolcro & 43.57 & 12.14 & & VIII & \\
\hline Pieve Santo Stefano & 43.67 & 12.04 & & VII & \\
\hline Città di Castello & 43.46 & 12.24 & & $\mathrm{~V}$ & \\
\hline 1668 August 22 & 43.51 & 12.58 & VI & & 4.6 \\
\hline Città di Castello & 43.46 & 12.24 & & VI & \\
\hline Sansepolcro & 43.57 & 12.14 & & $\mathrm{~V}$ & \\
\hline 1690 March $22 \quad 21: 50$ UT & 43.46 & 12.24 & VI-VII & & 5.1 \\
\hline Città di Castello & 43.46 & 12.24 & & VI-VII & \\
\hline 1693 February 24 - 3:45 UT & 43.45 & 12.34 & VI-VII & & 5.1 \\
\hline Pietralunga & 43.44 & 12.44 & & VII & \\
\hline Città di Castello & 43.46 & 12.24 & & VI-VII & \\
\hline 1725 April 17 13:05 UT & 43.45 & 12.43 & VI-VII & & 5.1 \\
\hline Fabriano & 43.33 & 12.90 & & VII-VIII & \\
\hline Città di Castello & 43.46 & 12.24 & & VI & \\
\hline Sansepolcro & 43.57 & 12.14 & & VI & \\
\hline Perugia & 43.11 & 12.39 & & IV-V & \\
\hline 1731 March 29 & 43.67 & 12.04 & VII-VIII & & 5.5 \\
\hline Pieve Santo Stefano & 43.67 & 12.04 & & VII-VIII & \\
\hline
\end{tabular}




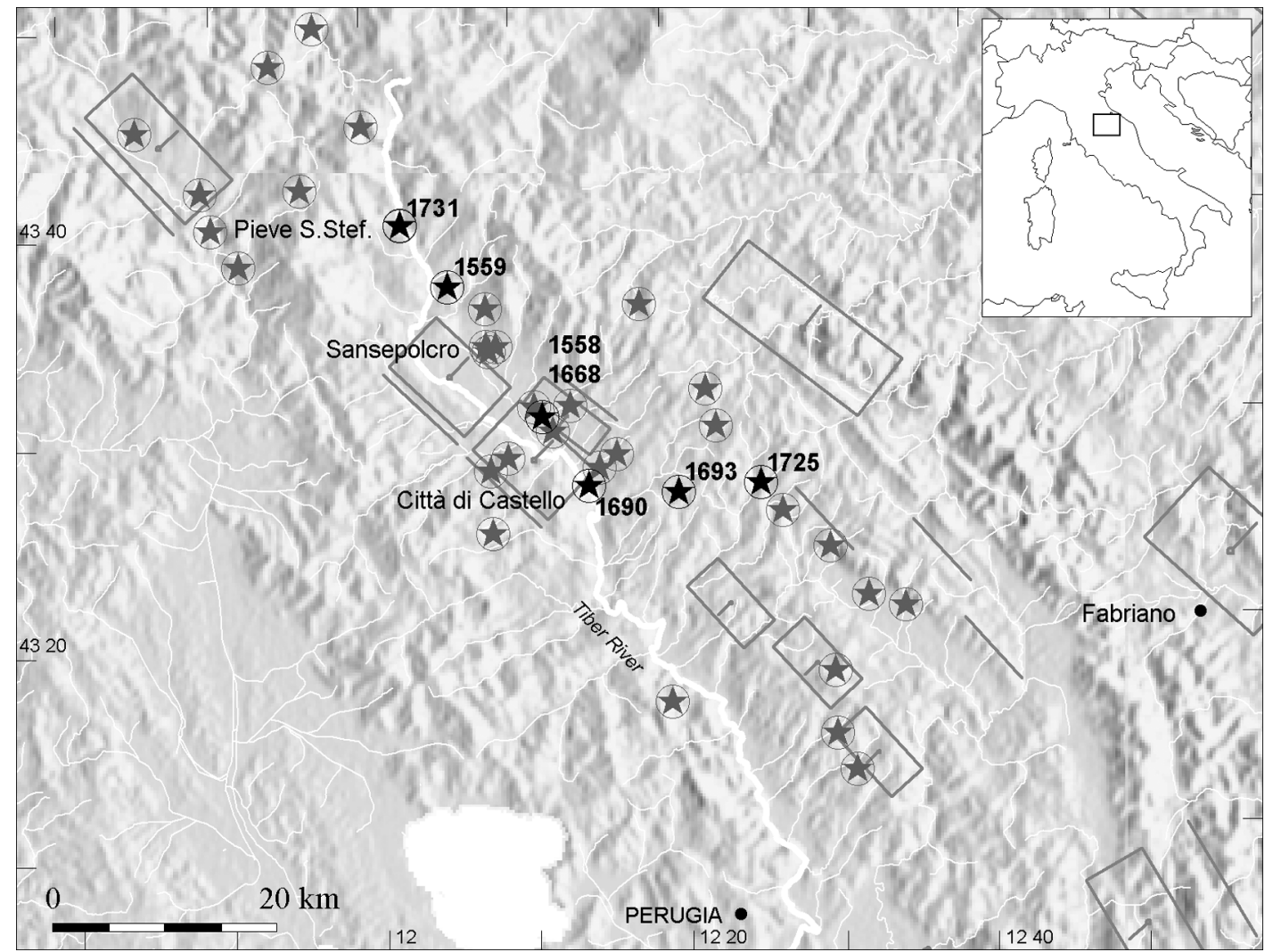

Fig. 2. General map of the epicentres: in grey the already known earthquakes (see table I) in black the new events; the data overlap with the map of the active faults contained in the DISS 3.0 database (DISS Working Group, 2005).

(Memorie della Comunità, regs. 1-3). An equally negative outcome was produced by the research at the Municipal Historical Archives of Città di Castello, where we consulted the series Riformanze (reg. 126) and Lettere (tome 8).

On 11th March 1731 the first shocks were felt, and were frequently repeated in the subsequent days. The inhabitants of Pieve Santo Stefano abandoned their homes and moved out to the countryside. The town was virtually deserted.

11th-15th March 1731: seventy shocks are mentioned, probably initially of intensity between IV and V degree of MCS scale;

29th March 1731: the most violent shock caused the collapse of many houses at Pieve Santo Stefano.

\section{Research results and conclusions}

This research has unearthed seven earthquakes (amongst which a sequence of more than 70 shocks) that occurred between 16th century and 18th century, previously unknown to the catalogues currently in use. The evaluated magnitude ranges between 4.6 and 5.5. The results of the research allow us to classify 18 effects in 6 sites (see table II and fig. 2).

The research method applied here has proven to be valid in 'capturing' unknown seismic events of medium and low intensity, very frequent both in the Upper Valtiberina as well as in other Apennine areas of the Italian Peninsula. As a very large wealth of documents is 


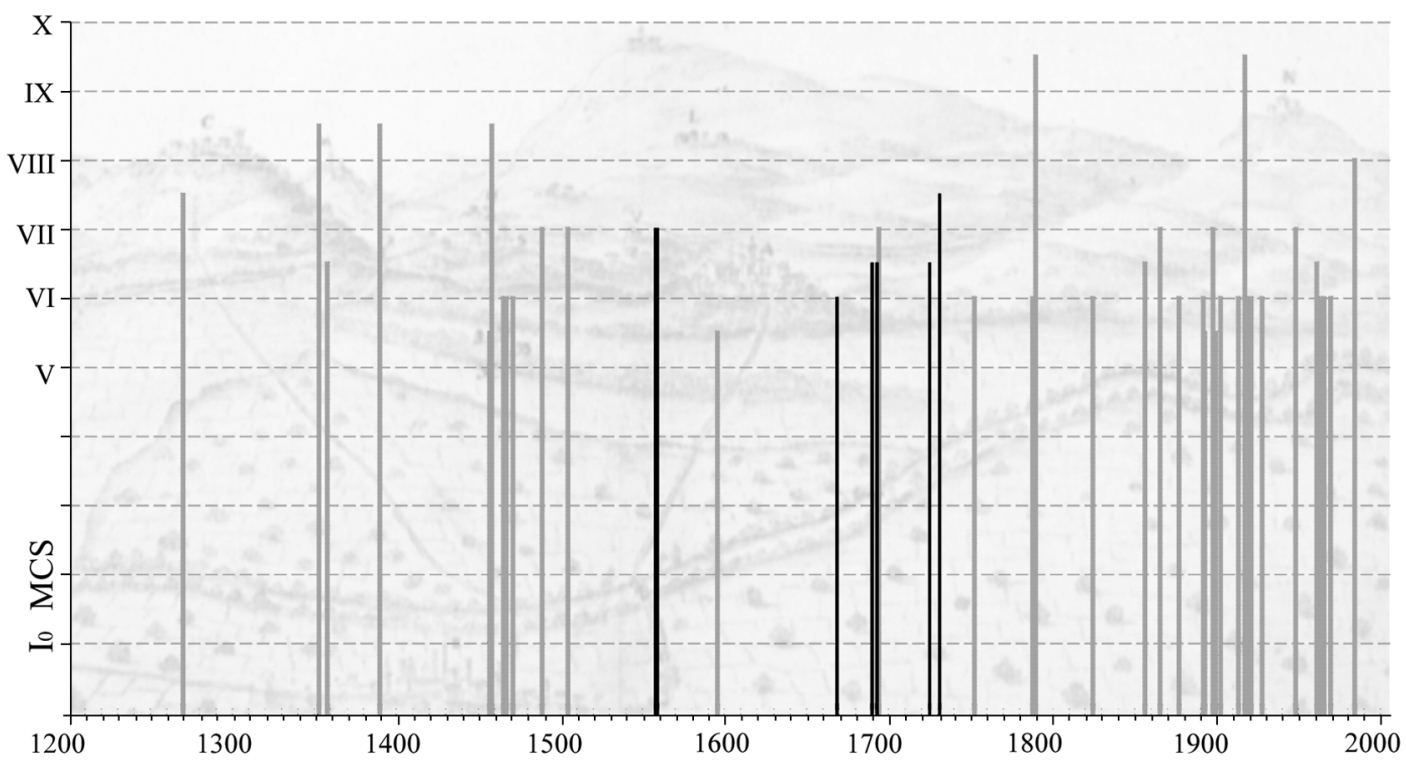

Fig. 3. In grey earthquakes with epicentre in the Upper Valtiberina from the 13th to the 20th centuries from CFTI (2000) and CPTI (2004): they are 47 events with $\mathrm{I}_{0} \geq \mathrm{V}$-VI; in black the 7 earthquakes brought to light by the current research (in the background: 17th century map of the Upper Valtiberina, preserved in the State Archives of Florence).

available, the chance to detail and enhance the basic historical data is therefore only related to the priorities that have been set for the various research strands. This case study has indeed highlighted the fact that retrieving new data can be made rather straightforward by performing systematic and crossed checks of the different types of sources.

As concerns the area being examined, the results, while not changing the previously known picture of the seismicity, nonetheless complete the historical series of the earthquakes (fig. 3) and improve the local estimates of seismic haz- ard, above all in relation to the frequency of the events.

\section{Acknowledgements}

We would like to thank Dr. Andrea Daltri and Dr. Martino Ferrarese, who performed the archival research for the SGA workgroup, the former at the State Archives of Florence and in the Municipal Historical Archives of Città di Castello and Sansepolcro, the latter at the State Archives of Rome.

\section{Appendix}

Selection of the unpublished sources used in this study and cited in the text. The documents are transcribed here in the orginal languages (Italian and Latin).

\section{doc. 1}

8th-10th February 1558 - Sansepolcro, Città di Castello

Municipal Historical Archives of Sansepolcro, series II, Riforme, provvisioni e deliberazioni dei consigli, reg. 14 (1557-1562), fol. 40r. 


\section{Adj .27. del detto}

[...]

Ricordo come del detto mese di febbraio furono terribili, et spaventevoli terremuoti non solo nella nostra città, ma ancora nelle città convicine, et massime in la Città di Castello dove si vedonono tutte le case piene di puntelli, i quali cominciorno adj .9. del detto, a hore cinque di notte nella quale hora ne vennono due di tal sorte che sbigottirono tutte le persone della detta città, massime che di poi sonate di poco le sei hore ne rinovorno delli altri benché piccoli, ma alle undicj ne venne un altro terribilissimo et alle .13. il terzo pur grande, di sorte che si ordinò che si dovessino chiudere tutte le botteghe, et si fece dire, et celebrare in la chiesa Cattedrale la messa dello Spirito Santo et si ferono le processioni, et a .10. del detto a hore .19. se ne sentì un altro di sorte che fece tremare quasi gl'huomini ch'erono alla campagna, et fra detti grandi terremuoti sempre ne venevono delli piccoli delli quali non si puoté tenere conto, di maniera che veduto i detti signori consiglieri la città tutta sbigottita, molti caminj, muri, et tetti rovinati, guasti, et discoperti per tali terremuoti insieme con il signor vicario del reverendissimo monsignor nostro si feciono venire i Capuccini, et adì undicj si feciono le orationi delle quaranta hore le quali cominciorno a hore .19. con grandissima devotione, et in mentre si sentivono spesse volte pur delli terremuoti, i quali poi parse si placassino benché tutto il detto mese durassino pur furno piccoli, et non di meno ferno per paura quasi impallidire tutta la città.

11th April 1559 - Sansepolcro

doc. 2

Municipal Historical Archives of Sansepolcro, series II, Riforme, provvisioni e deliberazioni dei consigli, reg. 14 (1557-1562), fol. 78r.

Adj .xi. d'aprile .1559.

Ricordo come detto dì circa un'hora et mezza di notte venne uno terribile, et spaventevole terremuoto, che fece cadere circa dugento caminj, et durò pur assai, per il che il reverendissimo monsignor nostro ordinò che si facessi horatione della pace da durare .40. ore, et dette hore fu fatta una divota horatione nella quale andorono i signori consiglieri, le compagnie tanto delle donne, quanto delli huomini, et tutte le arti dj sorte che ciascuna compagnia vi stette una sol hora, et furono di sorte che spaventorno tutti gl'huominj, et molti cominciorno ad habitare fuori, et tutto il giorno, et la notte si andava in processione: et fu da tutti i vecchi cittadinj detto che mai si era sentito il più terribile: et furno eletti sopra detta oratione per i magnifici signori consiglieri di commissione di monsignor nostro reverendissimo Lodovico di Francesco Guelfi, Roberto di Luca Pichi, Salvestro Carsidonij, Nicolò di messer Nicolò Tanj.

\section{1th April 1559 - Città di Castello}

doc. 3

Municipal Historical Archives of Città di Castello, Riformanze, reg. AA (1559), fol. 34r.

\section{Terremotus}

Fuit terremotus satis notabilis tamen absque noxa alicuius circa horam cum dimidia noctis sequentis diem martis undecima mensis aprilis 1559.

\section{1th April 1559 - Pieve Santo Stefano}

doc. 4

State Archives of Florence, Cinque conservatori del contado e dominio fiorentino, Lettere, file 352 (1559-1560), Letter by the ducal vicar Zanobi Guidotti, Pieve Santo Stefano 26th April 1559.

Mi occorre avvisare Vostra Signoria come 15 giorni sono venendo li tremuoti in questo loco hanno facto non pocho di danno a una cantonata del palazo quale per essere antichissimo et la muraglia non esser più buona che si bisogni: potarebe andare in terra non riparando, sì ancora alle doccie del palazo: quale non sendo più buono l'aqua fa alquanto di danno alla facciata: però quando piacessi a Vostra Signoria che se ispendessi [...] se ripararebe a tutte queste cose $[\ldots]$.

\section{1th April 1559 - Pieve Santo Stefano}

doc. 5

State Archives of Florence, Cinque conservatori del contado e dominio fiorentino, Lettere, file 352 (1559-1560), Letter by the ducal vicar Zanobi Guidotti, Pieve Santo Stefano 22nd May 1559.

Si replica per le presenti a Vostra Signoria come un mese fa venendo li tremuoti in questo loco hanno fatto un 
pocho di danno a una cantonata del palazo quale per essere antichissimo et la muraglia non esser più buona che si bisogni potarebe andar in terra se non si riparassi, sì ancora alle doccie del palazo quale non sendo più buono l'aqua fa alquanto di danno alla facciata però quando piacessi a Vostra Signoria di compiacersi che si ispendessi $[\ldots]$ si ripararebe al tutto $[\ldots]$.

\section{2nd August 1668 - Città di Castello}

doc. 6

State Archives of Rome, Congregazione del Buon Governo, series II (Atti per luoghi), Città di Castello III, bdl. 1085 (1667-1682), Letter by the governor Girolamo Castromediano, Città di Castello 23rd August 1668.

Col ritorno dell'accluso memoriale dato in cotesta Sacra Congregazione da questa Comunità in proposito dell'arco che minaccia rovina nella sala di questo palazzo ove risiedo colla mia famiglia devo rappresentare a Vostra Eminenza la necessità del resarcimento colla maggior celerità che si puole, et il pericolo evidente al quale io medesimo e detta mia famiglia soggiaccio, con tutti gl'altri che vengono a trattare li loro interessi, essendo questo nel primo ingresso alle mie stanze. Soggiungo che iheri appunto da un terremoto hebbe detto arco una scossa pericolosissima a tal segno che se non si fusse provveduto con un appoggio di un trave poteva succedere la caduta con portarsi a terra tutti $i$ tetti, al che non solo non bastarebbero li scudi sessanta ma ci havrebbe apportato dispendio assai maggiore, onde supplico Vostra Eminenza per la celerità della domandata licenza perché si possa evitare et il pericolo e la spesa, che potrebbe avantagiarsi, ch'è quanto devo in risposta dell'umanissima sua in data li 28 prossimo passato.

\section{2nd March 1690 - Città di Castello}

\section{doc. 7}

State Archives of Rome, Congregazione del Buon Governo, series II (Atti per luoghi), Città di Castello IV, bdl. 1086 (1683-1700), Plea by the rector of the Jesuit College father Filippo Guarnerio, Città di Castello ante 23rd August 1690 .

Foris. All'illustrissimi signori confaloniere e priori dell'illustrissima Città di Castello per il padre rettore del Collegio della Compagnia di Giesù.

Intus vero. Illustrissimi signori. Doppo il terremoto della prossima passata Quaresima notabilmente apertesi le muraglie del Collegio de padri Giesuiti gl'han necessitati ad abandonare l'habitatione d'una parte di esso per timore di non restare ad un'altra simile scossa sepolti da improvisa ruina. Non essendo questa evitabile in altra maniera, che col finire la fabrica incominciata perché resti rinfiancata la muraglia di fianco che è quella che cede priva d'appoggio doppo il distaccamento delle case contigue. Né havendo il Collegio per il diminuimento dell'entrate nell'ultima estrattione de monte che a pena son sufficienti ad alimentare un picciol numero de padri assegnamento tale con che provedere al presentaneo bisogno per non tornarsi ad aggravare di nuovi debiti che fu uno de motivi, che persuase la partenza gl'anni adietro de padri, il padre rettore supplica l'illustrissime Loro Signorie di un grazioso prestito sino alla somma di ottocento scudi del deposito, che si trova nel Monte della Pietà spettante all'Abondanza di cotesto publico, obligandosi annualmente con l'avvanzo delle proprie entrate a reintegrare detto deposito in quella forma che sarà accordata respettivamente alla povertà del Collegio e con altra obligazione in caso di carestia o necessità del publico di sborsare ogni residuo che in quel tempo si trovarà debitore e perciò impegnarebbe il denaro che estrae da suoi luoghi de monti in Roma fondazione di questa illustrissima città. Persuade l'oratore il porgere la presente supplica sì per non trascurare ogni mezzo doppo d'haverne tentati molti, sì perché non siegui la ruina imminente con gran pregiuditio di maggior spesa, la quale non potendosi riparare con più migliara di scudi ci necessitarebbe a nuovamente partire com'anche per tor via ogni spavento a padri che l'abitano a non servirli di buon talento, come merita la loro cortesia dalla quale l'oratore spera un gratioso rescritto. Quam Deus etc.

\section{2nd March 1690 - Città di Castello}

\section{doc. 8}

State Archives of Rome, Congregazione del Buon Governo, series II (Atti per luoghi), Città di Castello IV, bdl. 1086 (1683-1700), Letter by the governor Gian Francesco Ruota, Città di Castello 18th February 1691.

Questi padri Giesuiti hanno supplicato la Sagra Congregazione del Buon Governo con l'accluso memoriale che qui ritorno all'Eminenze Vostre per il beneplacito di poter conseguir l'imprestito di scudi 800 accordatoli secondo il decreto del Consiglio parimente qui ingionto ad effetto di poter continuare la fabrica del loro Colleggio che rimasta imperfetta da alcuni lati patì notabile scossa dal terremoto dell'anno scorso quì sentito per non essere fi- 
ancheggiata da muri sufficientemente, ond'è che scarseggiano di sicura habitatione e bastante per il numero de padri. E però condesceso il pubblico colla dovuta riserva dell'assenso della Sagra Congregazione d'imprestarli detta somma degl'effetti dell'Abbondanza che qui si trovano indisposti circa scudi 5 mila, tanto più che si obligano di restituirne scudi 50 l'anno, et in caso di bisogno dell'Abbondanza promettono di rendere anco l'intiera somma sottoponendo tutti li loro beni, e precisamente 10 mila scudi di luoghi di monte, di modo che resta assicurato l'imprestito et insieme stabilito l'incolato di questi padri nella città a benefizio di cui contribuiscono molte opere così spirituale che temporalmente, né senza gran pregiudizio restarebbe priva dell'assistenza di questi religiosi, come altra volta è seguito con detrimento notabile, ch'è quanto parmi dover riferire all'Eminenze Vostre in questo proposito.

\section{2nd March 1690 - Città di Castello}

doc. 9

\section{2nd-24th February 1693 - Città di Castello, Pietralunga}

Municipal Historical Archives of Città di Castello, Riformanze, reg. 116 (1690-1693), fol. 89v.

Il detto terremoto si è fatto sentire in più posti d'Italia, come parimente qui in Città di Castello la notte delli 23 di febbraio precedente alla festa di San Mattia Apostolo su le hore 10 e 1/2 validamente, non meno di quello che seguì il martedì 22 marzo 1690 che scosse la città e bona parte del territorio nell'hore 4 in circa, ambi da me pur troppo sentiti con gravissimo timore per le mie molte colpe. La Domenica precedente alli 23 di questo mese di febbraio circa le hore 15 di già si fece sentire il terrore del terremoto, che in Pietra Longa replicò per più fiate in diverse giornate a segno, che obligò gl'assistenti e recorsi nella chiesa della Pieve, a ritirarsi, e fuggire all'aperto per scappare dalle minacciose ruine soprastanti a cagione della frequenza del terremoto che non cessa, se bene per la divina grazia senza nocumento, non mancandosi di ricorrere alla misericordia di Dio con pubbliche processioni, esposizioni del Santissimo nella Cattedrale, pubbliche penitenze promosse dalla pietà del reverendissimo Capitolo in assenza di monsignore vescovo e dal zelo de padri della Compagnia di Giesù seguitati dall'universale scoprimento della divota, e veneratissima santa imagine di San Florido protettore amatissimo di questa città.

\section{7th-18th April 1725 - Città di Castello}

doc. 10

Municipal Historical Archives of Città di Castello, Riformanze, reg. 125 (1724-1727), fols. 83v.-84r.

\section{Terremotus maximus}

Die martis decima septima aprilis 1725 ora decima octava, et tribus quadrantibus pulsatis ingens venit terremotus, taliter quod nisi divina assistentia substinuisset collabi edificia deberent, et tamen Deo dante nullum notabile damnum passa fuit civitas, quo pacto illustrissimus dominus confalonierus mandavit pulsari campanam publicam ad effectum convocandi consiliarios, tam Consilii regiminis, quam Consilii credentie prout convocati fuerunt etiam per famulos, ad effectum ut una cum magistratu ad ecclesiam Sancte Marie Gratiarum primarie protectricis ad agendas gratias se conferrent prout maximo nobilium numero et aliorum civium comitatu illustrissimus dominus confalonierus una cum Magistratu se contulit, ibidem perventi a patribus Servorum suscepti ante scalas porte maioris, ingressique templum fuerunt recitate varie preces, et reversi sunt palatium publicum.

Die decima octava

Idem illustrissimus dominus confalonierus ad petendam operam divinam, et liberationem civitatis a flagello terremotus una cum illustrissimis dominis prioribus se contulit ad visitandam ecclesiam, corpus, et immaginem Sancti Floridi protectoris concivis, et episcopi civitatis ubi ad altarem sacre immaginis sacrosanto sacrificio misse assisterunt deinde reversi fuerunt palatium publicum.

[...] Die dicta

Eadem fere ora fuit licet aliquanto minor novus terremotus, et Deo dante civitas nullum damnum passa fuit.

\section{1th-29th March 1731 - Pieve Santo Stefano}

doc. 11

State Archives of Florence, Manuscripts, 125-147, Francesco Settimanni, Memorie fiorentine, vol. 15, fols. 546r. and $549 \mathrm{v}$. [The author uses for the dating the style of the Florentine Incarnation that sets the start of the year to 25th March]. 
Addì 11 di marzo 1730 [=1731] nella terra della Pieve a Santo Stefano si cominciarono a sentire varie scosse di terremoto le quali continuarono molto frequenti per molti giorni.

$[\ldots]$

Addì 29 di marzo 1731 giovedì nella terra della Pieve di Santo Stefano venne una scossa di terremoto la quale gettò a terra molte case, ma non seguì mortalità di uomini, perché per le precedenti scosse stavano già tutti quegli abitanti alla campagna.

\section{REFERENCES}

Unpublished sources

State Archives of Arezzo

Antico Comune, Deliberazioni e partiti dei priori e del consiglio generale, reg. 23 (1552-1558); reg. 24 (15581563).

Antico Comune, Registri di lettere dei cancellieri, reg. 6 (1557-1559); reg. 7 (1559-1560).

State ARChives of Florence

Capitani di parte guelfa, Numeri neri, Suppliche, file 706 (1557-1558); file 707 (1558-1559).

Cinque conservatori del contado e dominio fiorentino, Lettere, file 348 (1557-1558); file 349 (1558-1559); file 350 (1558-1559); file 352 (1559-1560).

Cinque conservatori del contado e dominio fiorentino, Copialettere, reg. 310 (September 1557-February 1558); reg. 311 (March 1558-August 1558); reg. 312 (September 1558-February 1559); reg. 313 (March 1559-August 1559).

Cinque conservatori del contado e dominio fiorentino, Deliberazioni, reg. 134 (March 1557-February 1558); reg. 135 (March 1558-February 1559); reg. 136 (March 1559-July 1559).

Manuscripts, 125-147, Francesco Settimanni, Memorie fiorentine, 18 voll., 18th cent.

State Archives of Rome

Congregazione del Buon Governo, series II (Atti per luoghi), Città di Castello III, bdl. 1085 (1667-1682); bdl. 1086 (1683-1700); bdl. 1089 (1721-1735).

Municipal Historical Archives of Città di Castello

Riformanze, reg. 58 (1555-1558); reg. AA (1559); reg. 110 (1666-1669); reg. 116 (1690-1693); reg. 125 (17241727); reg. 126 (1728-1731).

Lettere, tome 4 (1663-1679); tome 5 (1680-1699); tome 7 (1716-1729); tome 8 (1730-1738).

Municipal Historical Archives of SANSEPOlcro

Series II, Riforme, provvisioni e deliberazioni dei consigli, reg. 14 (1557-1562); reg. 31 (1649-1670); reg. 33 (1692-1708); reg. 35 (1724-1740).

Series V, Copialettere del magistrato e suppliche al principe, reg. 2 (1550-1572); reg. 3 (1553-1577).

Series VII, Corrispondenza dei cancellieri, file 7 (16901697); file 10 (1726-1729); file 13 (1729-1731).

Series XXX, Memorie della Comunità, reg. 1 (1567-1781); reg. 2 (1705-1806); reg. 3 (1589-1795); reg. 4 (14411699).
Augusta Civic Library of Perugia

Manuscripts, 1398, n. 35, Pietro Vermiglioli, Diario (16921742).

Civic LibRARY OF SANSEPOLCRO

Manuscripts, J.107, Continuazione della cronaca del Borgo San Sepolcro di Francesco Bercordati, 17th-18th century.

Manuscripts, J.109, Francesco Giuseppe Pignani, Compendio istorico di memorie fedelmente raccolte intorno alla origine, fondazione e proseguimento della città di Sansepolcro diviso in memorie, 1758.

\section{Published sources}

Alberti Berto (1525-1599): Memorie, edited by G. Degli AZZI VitellesCHI, Gli Archivi della Storia d'Italia, 2nd series, 4 (9), 1970, 197-211, Rocca San Casciano.

Pellini Pompeo (1523-1594): Della Historia di Perugia. Parte terza, Fonti per la storia dell'Umbria, n. 8, 1915, Perugia.

Newspapers

Bologna, 17th March 1693, [n. 11], Bologna.

Bologna, 15th May 1725, n. 20, Bologna.

Gazzetta di Mantova, 11th May 1725, n. 19, Mantua.

Gazzetta di Mantova, 30th March 1731, n. 13, Mantua.

Studies and Catalogues

Boschi, E., E. Guidoboni, G. Ferrari, D. Mariotti, G. VALENSISE and P. GASPERINI (Editors) (2000): Catalogue of Strong Italian Earthquakes from 461 B.C. to 1997, Ann. Geofis., 43 (4), 609-868 (with CD-ROM) (here also as CFTI 3, previous editions 1995, 1997).

CAstelli, V. (2002): Il terremoto del 1789 a Città di Castello: ricostruzione dell'impatto e della distribuzione dei danni a partire da documenti inediti, Ingegneria Sismica, 19 (1), 78-85.

Castelli, V. (2004): Between Tevere and Arno. A preliminary revision of seismicity in the Casentino-Sansepolcro (Tuscany, Italy) area, Boll. Geofis. Teor. Appl., 45 (1-2), 35-49.

Castelli, V., G. Monachesi and M. Stucchi (Editors) (1997): La Sismicità Maggiore dell'Appennino UmbroMarchigiano, CNR-GNDT Report (unpublished).

CPTI Working Group (2004): Catalogo Parametrico dei Terremoti Italiani, CPTI04 (INGV, Bologna; available on line at: http://emidius.mi.ingv.it/CPTI/). 
DISS WorkING GRoup (2005): Database of Individual Seismogenic Sources (DISS), Version 3.0.1: a Compilation of Potential Sources for Earthquakes Larger than M 5.5 in Italy and Surrounding Areas (available on line at: http://www.ingv.it/banchedati/banche.html).

Ferrari, G. and C. MARMo (1985): Il «quando» del terremoto, in Terremoti e Storia, Quad. Storici, n.s., 60, 691-715.

Gasperini, P. and G. Ferrari (2000): Deriving numerical estimates from descriptive information: the computation of earthquake parameters, in CFTI 3, Ann. Geofis., 43 (4), 729-746.

Guidoboni, E. (2000): Method of investigation, typology and taxonomy of the basic data: navigating between seismic effects and historical contexts, in CFTI 3, Ann. Geofis., 43 (4), 621-666.

Guidoboni, E. and A. Comastri (2005): Catalogue of Earthquakes and Tsunamis in the Mediterranean area from the 11th to the 15th century (INGV-SGA, RomaBologna), pp. 1034.

Guidoboni, E., A. Comastri and G. Traina (1994): Catalogue of Ancient Earthquakes in the Mediterranean
Area up to the 10th Century (ING, Roma-SGA, Bologna), pp. 504.

Guidoboni, E., C. Ciuccarelli and D. Mariotti (2001): Catania alla fine del Seicento e i terremoti del gennaio 1693, in Catania, Terremoti e Lave: dal Mondo Antico alla Fine del Novecento, edited by E. Boschi and E. GUIDOBONI (INGV-SGA, Roma-Bologna), 105-166.

Mariotti, D., A. COMASTRI and E. GUIDOBONI (2000): «Unknown» earthquakes: a growing contribution to the Catalogue of Strong Italian Earthquakes, in CFTI 3, Ann. Geofis., 43 (4), 787-795.

SGA-INGV (1999): Indagini Storiche in Zone «Silenziose»: Area di Sansepolcro, RPT 218/99 (unpublished report available at the Central INGV Library in Rome).

SGA-INGV (2000-2001): Recupero e Integrazione di Informazioni su Terremoti Attualmente Sconosciuti ai Cataloghi in Uso, RPT 227/00, RPT 234/0 (two unpublished reports available at the Central INGV Library in Rome).

(received February 28, 2005; accepted February 17, 2006) 